\title{
偏心鉄筋コンクリート構造物の非線形変形モードに基づく地震応答推定手法 A METHOD OF ESTIMATING EARTHQUAKE RESPONSES OF ASYMMETRIC REINFORCED CONCRETE STRUCTURES BASED ON NONLINEAR DEFORMATION MODES
}

\author{
壁谷澤 寿一*，壁谷澤 寿海** \\ Toshikazu KABEYASAWA and Toshimi KABEYASAWA
}

\begin{abstract}
The paper presents a method of estimating earthquake responses of asymmetric reinforced concrete structures based on nonlinear deformation modes. Shaking table tests of one-third scale six-story eccentric reinforced concrete wall-frame specimens were conducted and analyzed with a nonlinear three-dimensional frame model. A fair correlation was observed between the test and the frame analysis. Several wall-frames were designed by varying the plan, location and stiffness of the walls from the specimen to simulate general cases of torsional responses, where the 2 nd mode is dominant as well. The intensities of the earthquake motions for the simulation were also varied to simulate also wide range of structural responses from elastic to inelastic deformations. The dominant modes were derived from the nonlinear responses, in which general characteristics were discussed in terms of effective mass ratio. The value approaches a constant when the inelastic response is large. The constant could be derived from nonlinear pushover analysis considering the first mode and the second mode in the assumed load vectors. A new method of estimating nonlinear responses based on the deformation modes in the dynamic responses are proposed based on the general characteristics. The estimates are compared with the results of nonlinear dynamic frame analysis, where a better correlation was observed than those by past simple methods generally from elastic to inelastic responses.
\end{abstract}

Keywords : Eccentric frames, Reinforced concrete, Shaking table test, Equivalent linearization, Nonlinear pushover analysis, Effective mass ratio, Mode superposition

偏心構造物, 鉄筋コンクリート, 震動台実験, 等価線形化, 非線形溸増載荷解析, 有効質量比, モ一 ド重合

\section{1. 研究目的}

2000年 6 月に施行された建築基準法における限界耐力計算では設 計用地震動の線形応答スペクトルから等価線形系によって非線形地 震応答を推定する方法が示されている。構造物の笖答は等価 1 自由 度系に縮約して代表変位の芯答を求め，1次モ一ドを基本にした静 的漸増解析との併用により各部材の最大岕答值を評価している。し かしながら，一般に偏心構造物の応答では最低でも並進が支配的な モード形と回転が支配的なモード形の 2 つのモ一ド形を考慮する必 要がある。構造物の形状によっていずれかのモード形が十分に支配 的であれば 1 次モードによる縮約でも非線形地震応答はある程度推 定可能であるが，2次モードも支配的になる場合は精度に限界があ る。そこで，限界耐力計算では偏心構造物への適用には制限が設け られている。

本研究では, 多層偏心鉄筋コンクリート（RC）構造物を対象にし て非線形地震偏心応答における支配的な変形モードの性状を明らか にするとともに，縮約系と等価線形化を基本にした応答推定手法を 提案して検証する。解析で用いる骨組レベルの非線形地震応答解析 手法は $1 / 3$ スケール 6 層偏心 RC 構造物の震動実験結果を解析する
ことによって妥当性を検証している。偏心構造物のパラメー夕は耐 震壁の配㯰や剛性によって変化させるが, 予備解析に基づいて支配 的なモード形抢よび㐫答の比率が広い範囲で異なる組み合わせを選 択的に想定して設定している。応答を推定する手法としては既往の 手法を基本にしているが, 変形モ一ドの性質に基づいて, より一般 性のある等価線形化手法を提案している。本研究の目的は, 非線形 偏心応答の一般的な性状を抽出して等価線形化による推定などに応 用することであるが，長期的には耐震設計基準や耐震診断基準にお ける割増し規定などの一般性を理論的に吟味することでもある。

\section{2. 既往の研究と解析手法}

\subsection{NPA と MPA}

偏心構造物の応答では 1 次モードのみが支配的な特殊な場合を除 いて最低でも 1 次と 2 次のモードを考慮する必要がある。1 次モ一 ド以外の影響も考慮して多層偏心 $\mathrm{RC}$ 骨組構造物非線形地震応答変 形を簡略に推定可能な方法として，2つ以上のモードを重ね合わせ た外力分布を設定して非線形漸増解析（Nonlinear Pushover Anal-
* 東京大学工学係研究科建築学専攻

** 東京大学地震研究所 教授
Graduate Student, Dept. of Architecture, Fac. of Engineering, University of Tokyo Prof., Earthquake Research Institute, University of Tokyo 
ysis, NPA)を行い，縮約 1 自由度形による応答と非線形漸增解析に よる変形分布によって応答を推定する手法例えば1 が提唱されている。 第 $\mathrm{i}$ 次モ一ドの固有変形モード形を $\{u\}_{i}=\left\{\phi_{d x i}, \phi_{d y i}, \phi_{\theta i}\right\}^{T}$, 刺激俰 数を $\beta_{i}$ とし, Nonlinear Pushover Analysis の外力ベクトル $\{F\} を$ 以下のように定義している。

$$
\{F\}=[M] \sum_{i} \beta_{i}\{u\}_{i}=[M] \sum_{i} \beta_{i}\left\{\phi_{d x i}, \phi_{d y i}, \quad \phi_{\theta i}\right\}^{T}
$$

$$
\beta_{i}=\frac{\left\{\phi_{d x i} \phi_{d y i} \phi_{\theta i}\right\}[M]\{\alpha\}}{\left\{\phi_{d x i} \phi_{d y i} \phi_{\theta i}\right\}[M]\left\{\phi_{d x i} \phi_{d y i} \phi_{\theta i}\right\}^{T}}
$$

$\phi_{d x i}:$ 第 $\mathrm{i}$ 次モ一ドの X 方向並進変形成分

$\phi_{d y i}:$ 第 $\mathrm{i}$ 次モードの Y Jj向並進変形成分

$\phi_{\theta i}:$ 第 $\mathrm{i}$ 次モードの層回転変形成分

$\beta_{i}$ : 第 $\mathrm{i}$ 次モードの刺激係数

$[M]$ : 質量マトリクス

$\{\alpha\}:\{1 \ldots, 1 \ldots, 0 \ldots\}^{T}$ : 入力加速度作用力向ベクトル

いくつかの解析対象ではこの手法により非線形地震心答の最大值

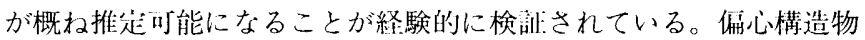
の失際の地等心答は，弾性あるいは大きく塑性化しない範用であれ

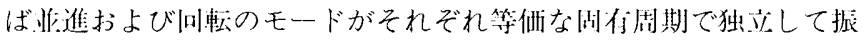

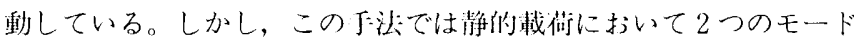

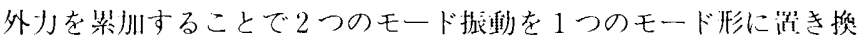
えている。すなわち，本于法は暗黙に1つの位相で非線形灿笭を衣

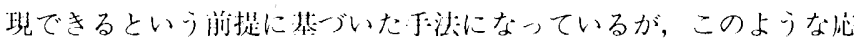
答性状が忡快に分析されたに:で邀川されているわけではない。

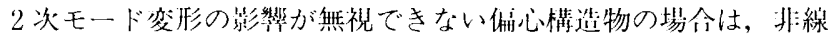

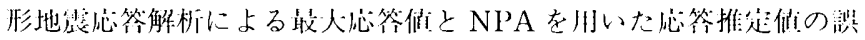

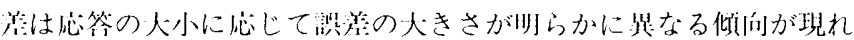

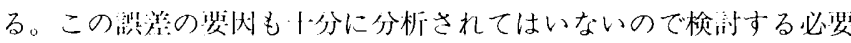

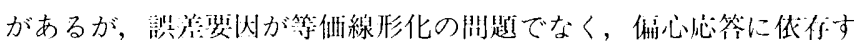

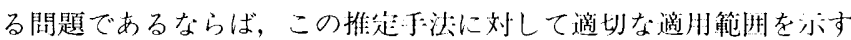

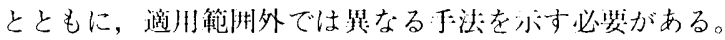

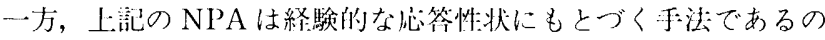
に対して，あくまで弹性志笭理諭にもとづいて，2つのモー-ド形を 考慮した等価線形化手法として挙げられるのがModal Pushover Analysis (MPA) 2)である。この手法は独立した(弾州) モード形に 对して非線形漸增載何解析から冬モード推定心答值を求める。その 変形の重る合わせた值を㤁答推定值とする。この手法は独立した モード形の合成であるので, 当然ながら弾性恥答およびひび割れ後 降伏前後の応答など，塑性化の程度が小さい場合については時刻歴 レベルでも応答推定の精度は高い。また, 最大応答に関してはSRSS 法などを用いることで各次応答モードの同時性を考慮して最大応答 を近似化することも可能である。しかし，大幅に塑性化したレベル の応答では $2 つ の$ 直交する固有モードが弾性時と同様に独立して振 動すると仮定する根拠は自明ではなく，検証されたわけでもない。 実際，この手法による推定值は塑性が進行すると徐々に応答推定精 度は低くなることが一般的な傾向として指摘されている2。

\section{2 有効質量比}

一般に第 $\mathrm{i}$ 次モードの忘答に与える影響の大きさを表す指標とし ては有効質量比 $M_{i}$ が用いられる。第I 次有効質量比は式(3)の形で
表される值であり，各モ一ド縮約系にかかる加速度あたりの外力の 大きさを示している。

$$
\begin{aligned}
& M_{i}=\left(\beta_{i}\{u\}_{i}^{T}[M]\{\alpha\}\right) / M \\
& M: \text { 構造物の総質量 } \\
& M_{i}: \text { i 次有効質量比 }
\end{aligned}
$$

既往の研究 ${ }^{3)}$ から単層一軸㨝れ構造物の固有モ一ドにおいて等価 質量比が 0.5 より大きい場合, 重心位置を挟んだ位置にある 2 構面の 加震方向の並進変形成分は異符号となり，0.5より小さい場合，同符 号となることが知られている。

この值は多自由度系 (多層構造物) のモード振動が応答に与える

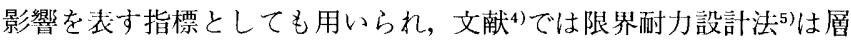
せん断力, 変形成分のモード相関を検討し， 1 次モ一ドが十分卓越 する場合として 1 次存効質量比 $M_{1}$ が 0.75 以上の水平多層構造物に 適用範囲を制限するとしている。

偏心構造物でも 1 次有效質革比によって1次モ一ドのみで举動が

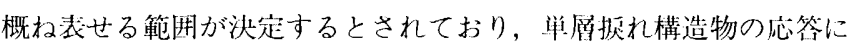

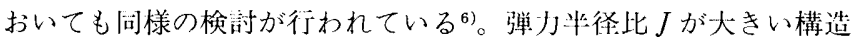

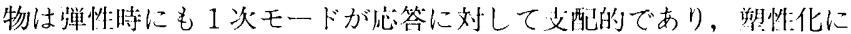

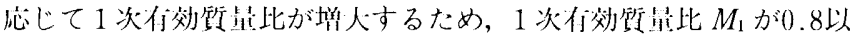
トになる埸命には，忍答が1次モード形で概ね推资できることを小゙ している。

以 1:の既往:の研究から，付效所话比は夰モードの動的な外少分们

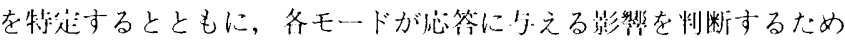
に行效な指槽となることがわかっている。

\section{3 動的モードの抽出法}

以トの検湖では，動的忍笒次の文酒讪なモード形（基準モ一ド）

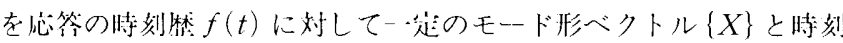
関数 $q(t)$ によって近似する $((4)$ 式)。所田マトリクス $[m]$ に圆して

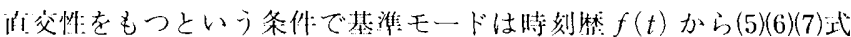
によって抽怙することができる7),8 。基準モ一ド形は（5)式による時

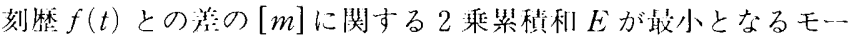
ド形で这㼁されるが，モード形 $\{X\}$ は式(7)にホされる湖们倠牒題の 最大古伯值に刘応する周有べクトル $\{u\}_{1 d}$ （1次）となる。

$$
\begin{aligned}
& f(t) \sim\{X\}_{q}(t) \\
& \left.\left.E=\int_{t_{2}}^{t_{1}}\left[f(t)-\{X\}_{q}(t)\right\}\right]^{T}[m][f(t)-\{X\} q(t)\}\right] d t \\
& {[R]=\int_{t 2}^{t 1}\{f(t)\}\{f(t)\}^{T} d t} \\
& ([m][R][m])\{u\}_{1 d}=\lambda_{1}[m]\{u\}_{1 d}
\end{aligned}
$$

また， 2 次以上の基準モードも応答時刻歴から（1次）基準モード を取り除いた成分に対して同様の手順により求められる。

\section{4 非線形漸増解析および地震応答解析の手法}

本研究では次項に示す偏心 $\mathrm{RC}$ 構造物の震動実験9 招よび実験結 果の解析を行い,解析手法および検討手法の妥当性を検証している。

部材レベルの非線形静的漸増載荷 (NPA) 解析抢よび地震応答解 析は CANNY9910)を用いた。柱梁には One-Component Model を, 
耐震壁にはTVLEモデル (Three Vertical Line Elements model $)^{11)}$ 用いた。各部材の強度㧍よび剛性低下率は日本建築学会 に基づく算定式 ${ }^{22)}$ をいた。各部材の曲げ復元力特性は TAKEDA モデル (除荷剛性低下指数 0.5$) と し$, 軸方向の復元力特性は Axial-

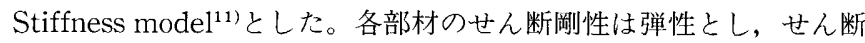
破壞はしないものとした。

なお，本解析では地震動は 1 万问入力としているが，以下の手法 は地震動が 1 方向入力であれば 2 軸偏心構造物一般に対しても地震 動の入力方向に対して構造物を解析すれば同様の手法が適用可能で ある。一方，地震動が 2 方向同時入力の場合は，偏心応答は地震動 の性質に遡って別途議論する必要があるが，地震動が支配的な主軸 方向で代表近似しうる場合には同様に 1 軸問題として扱うことが可 能である。

震動実験を等価 1 自由度系に縮約寸る際には, 震動実験結果から 抽出した基準（1次）モードで，震動試験体を 1 自由度系に縮約す る。その等価線形応答を非線形解析応答㧍よび塞験応答と比較する ことにより，1 次有効質量比の非常に大きな偏心構造物の挙動を等 価線形応答によって概ね把握できることを示し，その推定精度を検 討する。

また，1次モードのみ考慮した外力によるNPA とモードの重ね 合わせ外力 $(1+2$ 次モ一ド外力分布)による NPA を行い，有効質 量比が載荷ステップの変形に対してどのように推移するかを検討し た。非線形地震応答解析による応答結果から 1 次基準モードを抽出 し，最大応答変形のレベルに対する1次有効質量比の推移を NPA 結果と比較することで，変形モ一ドを特定するための NPA 手法の 妥当性を検証している。

\section{3. 震動実験と解析対象}

\section{1 震動実験の試験体と解析対象試験体}

震動実験の試験体は $1 / 3$ スケール 6 層 RC 偏心構造物である。図 1 右上に示すように入力方向（X 方向）に1スパン 3 フレーム，直交 方向に 2 スパン 2 フレームあり，それぞれ 1 枚の耐震壁が偏心して 配置されている。解析は震動実験の試験体を基本にした試験体で検 討した。四 1 に震動試験体と本稿で解析対象とする試験体 2 体の平 面図を示す。この 2 体は 1 次モードによる応答推定が難しいとされ る 1 次質量比が小さい場合を選択して示したものである。この 2 体 以外の偏心多層構造物についても偏心率や 1 次有効質量比が広い範 囲に分布するように設定して精度検証しているが，ややばらつきが あるものの同様の傾向を示す結果が得られている13)。

外力方向は X 万向とした。表 1 に震動試験体の部材断面リス卜， 表 2 に震動㧍よび解析対象試験体の緒元を示寸。解析対象試験体の 各部材断面, 1 スパン区画の重量も震動試験体に基づき同一とした。

実験は全く同一の試験体 2 体（試験体 $\mathrm{A}$, 試験体 B）に対して異 なる地震動を入力して実施した。表 3 に震動実験における加震履歴 を示す。大力による繰返し履歴が崩壊現象に与える影響を検討する ために試験体 $\mathrm{A}$ は継続時間の長い海洋型の地震動を低い入力レべ ルから漸増させる加震計画とし, 試験体 B は直下型の地震動を試験 体が若干塑性化し始好てら 1 回で非常に大きなレベルの大力を行 う加震計画とした。
表 1 部材断面リスト

\begin{tabular}{|l|l|l|l|l|l|}
\hline 柱 & $\mathrm{B} \times \mathrm{D}$ & $200 \times 200$ & 梁 & $\mathrm{B} \times \mathrm{D}$ & $150 \times 250$ \\
\hline & 主筋 & $12-\mathrm{D} 10$ & & 主筋 & $2-\mathrm{D} 10$ \\
\hline & 横補強筋 & $\mathrm{D} 4 @ 50$ & & 横補強筋 & $\mathrm{D} 6 @ 75$ \\
\hline 壁 & 壁厚 & 80 & 梁 & $\mathrm{B} \times \mathrm{D}$ & $240 \times 250$ \\
\hline & 縦横筋 & $\mathrm{D} 6 @ 100 \mathrm{~W}$ & 壁下 & 主筋 & $4-\mathrm{D} 10$ \\
\hline 各階重量 & 9.75 ton & & 横補強筋 & $\mathrm{D} 6 @ 75$ \\
\hline
\end{tabular}

表 2 構造物の緒元

\begin{tabular}{|l|l|l|l|l|l|l|}
\hline & $\mathrm{T} 1(\mathrm{~s})$ & $\mathrm{T} 2(\mathrm{~s})$ & $\mathrm{M} 1$ & $\mathrm{M} 2$ & $\mathrm{Re} 1$ & $\mathrm{Re} 2$ \\
\hline 解析試験体 SP1 & 0.178 & 0.109 & 0.261 & 0.503 & 0.396 & 0.134 \\
\hline 解析試験体 SP2 & 0.185 & 0.131 & 0.365 & 0.366 & 0.384 & 0.097 \\
\hline 震動試験体 & 0.203 & 0.074 & 0.573 & 0.019 & 0.884 & 0.215 \\
\hline
\end{tabular}

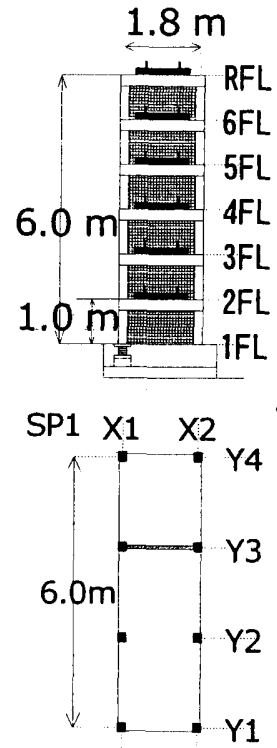

震動実験試験体

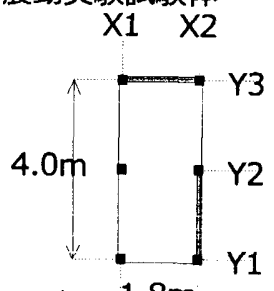

$1.8 \mathrm{~m}$

外力方向

\section{解析試験体例}

SP2

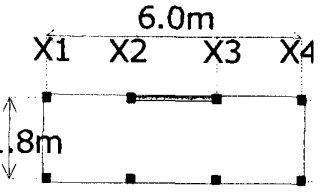

$1.8 \mathrm{~m}$

図 1 解析対象例と震動試験体

表 3 加震履歴

\begin{tabular}{|l|l|l|l|l|l|}
\hline \multicolumn{2}{|l|}{ 試験体 A } & \multicolumn{3}{l|}{ 試験体 B } \\
\hline run & 地震記録 & 倍率 & run & 地震記録 & 倍率 \\
\hline 1 & TOHOKU & 0.15 & 1 & TAKATORI & 0.06 \\
\hline 2 & TOHOKU & 0.30 & 2 & KOBE & 0.10 \\
\hline 3 & TOHOKU & 0.60 & 3 & KOBE & 0.20 \\
\hline 4 & CHILE & 0.25 & 4 & KOBE & 0.20 \\
\hline 5 & CHILE & 0.35 & 5 & KOBE & 0.60 \\
\hline 6 & CHILE & 0.45 & 6 & TAKATORI & 1.10 \\
\hline 7 & CHILE & 0.60 & & & \\
\hline 8 & CHILE & 0.90 & & & \\
\hline 9 & CHILE & 1.10 & & & \\
\hline 10 & CHILE & 1.10 & & & \\
\hline 11 & CHILE & 1.20 & & & \\
\hline
\end{tabular}

TOHOKU: 1978 宮城県沖地震 東北大学 (NS)

CHILE : 1985 チリ地震

KOBE : 1995 兵庫県南部地震 神戸海洋気象台 (NS)

TAKATORI: 1995 兵庫県南部地震 JR鷹取駅 (NS) 


\section{2 抽出モードの応答の比較}

非線形地震応答解析結果と実験結果の変位と復元力の関係を図 2 に示す。このような多層偏心構造物では単純に例えば最上階の変位 とべースシアの関係などを示す複雑な履尉形状を示す。そこで，同 図では，(4)式～(7)式によるモード抽出を行い, 抽出 1 次モードの復 元力一変位の関係を示した。また, 弾性 1 次モ一ド外力分布で静的 漸増載荷解析（NPA）した結果も同困に示した。なお, 非線形地震 応答解析は実験前に入力計画を特定するために予備解析として実施 したもので，実験結果によって特に修正はしていない。

実験結果抢よび非線形応答解析結果から抽出したモ一ドの復元力 一変位の関係は概ねよく近似しており, 特に試験体 A では最大変 形，周期がよく整合している。これに対して，試験体 B では run6に おいて，実験の強度は解析の降伏強度を上回っている。これは，降 伏前後の大力で試験体 $\mathrm{A}$ に比べて大きな速度, 変形レベルを与える 加震を行った試験体 B で歪み速度による影響が顕著に現れたこと， 2 試験体で抽出されたモ一ド形が異なること，などによると考えら れる。

眓 3 (a)に各加震時の抽计した 1 次モード㧍よび2 次モードの最人 水平変形角の推移を示す。横軸は最上階重心仿活の最人変形解であ る。2 試験体の 1 次，2次の抽计モード最人垐形の推移はほぼ等し く, 塑性化後も抽出 2 次モード変形の絶対憩は小さいことから試験 体の㐫答では 1 次モードの変形成分が!越していたことがわかる。

動実験結果から抽虬しな変形モードについてモード取大変形に

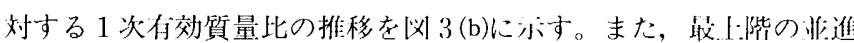
变形成分に対寸る回転変形成分の比の推移を汹 $3(\mathrm{c})$ に亦讨（この数

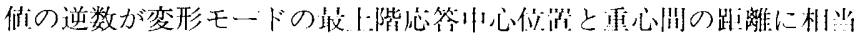
している)。2つの外力分布によるNPA 絬果はほぼ间一となった。 静的解析結果は震動実験と変形モ—ドの心筷心, 份効所代比とい う点でよく近似しており，実験結果から抽泝した変形モードは1次 外力分布によるNPAにより十分に高い精度で肺現しうることがが
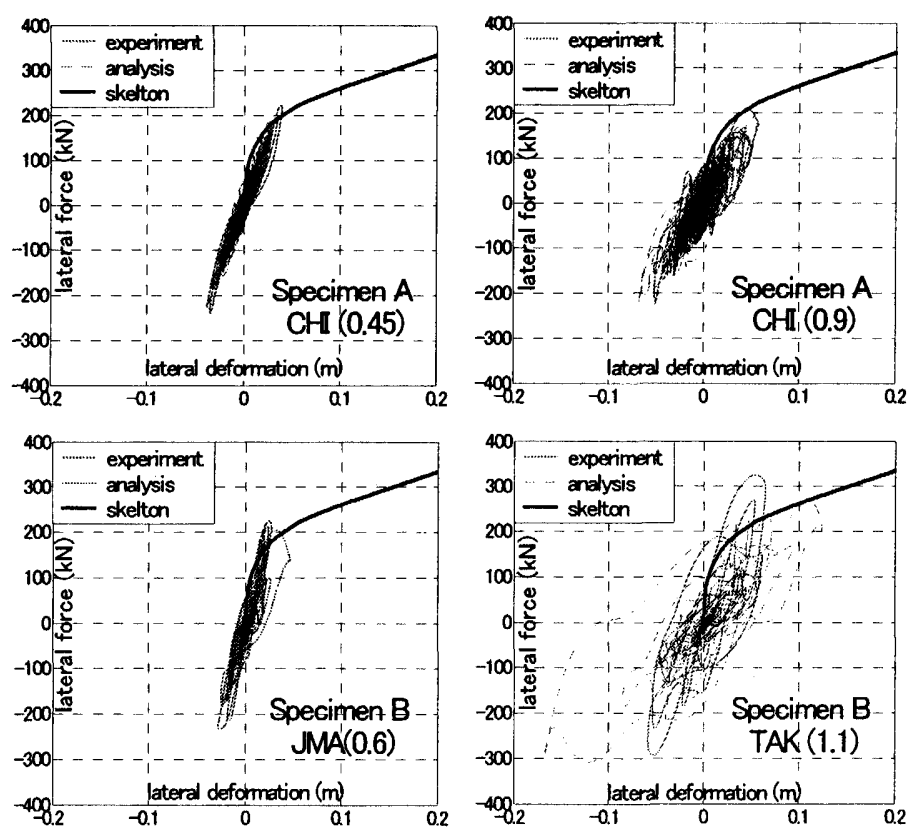
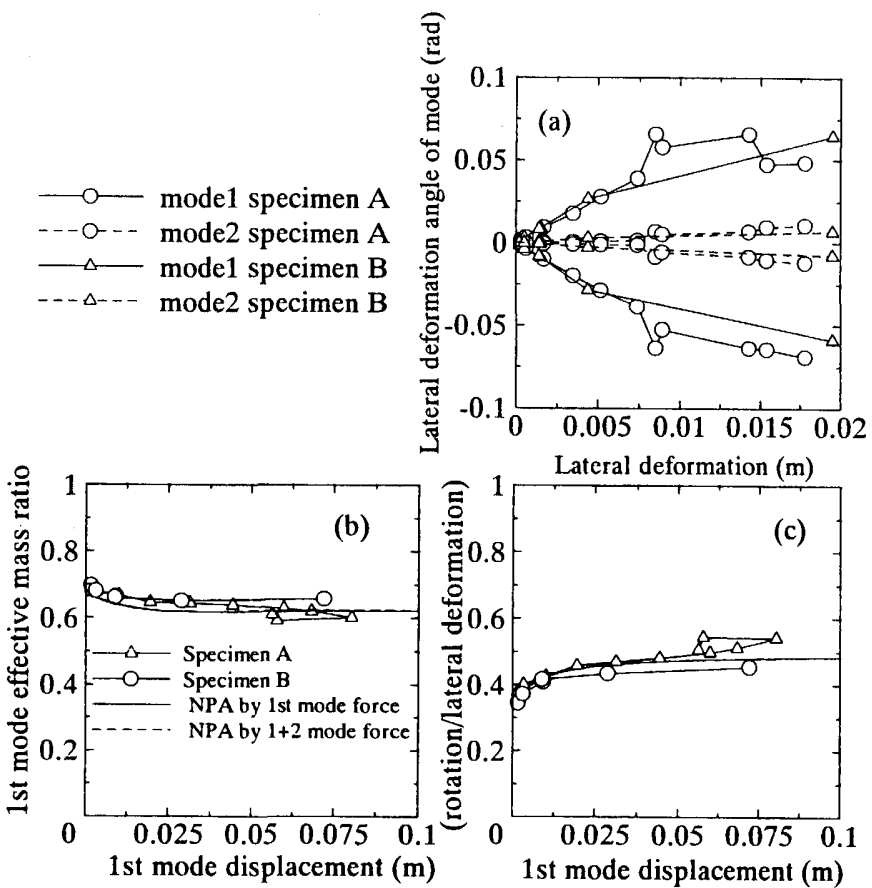

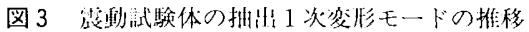

された。すなおち，このような構造物では 1 次モード緥約柔による 忘笭推分が叮能であることを小唆している。

\section{3 実験, 骨組解析，等価線形解析の比較}

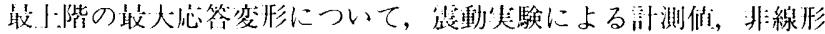

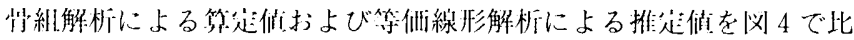

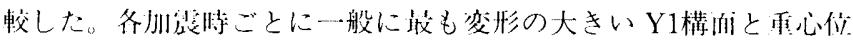

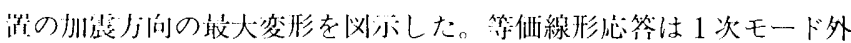

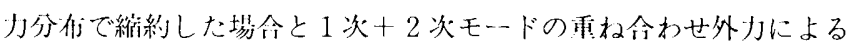

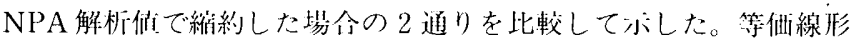

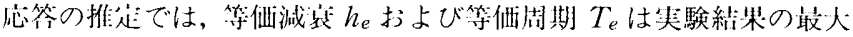

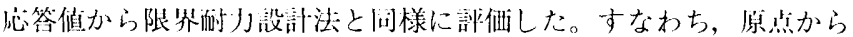
最大芯答点八の制線㴊性により等䛧胡期を算出し，等㑛減衰は略算 式による值として, SDF 時刻禁符解析を行った。非線形解析值と 実験結果は試験体 B の run6を除けば概ね垤している。これは急 激にせん断耐力が低下寸る試験体の挙動を解析モデルで考虑してい ないためであると考えられる。等価線形伈答値と非線形応答值は非 常に近似しており，その違いは実験俥と非線形忠答值の誤差に比べ ると小さかった。また，外力分布形による忘答推定値の違いもほぼ 無視できるものであった。以上により 1 次有効質量比がこの程度 (0.57)に大きい偏心構造物では実際の応答は 1 次モ一ドのみで縮約 した等価線形応答によって十分推定可能であることが実験的にも解 析的にも検証された。部材レベルの非線形地震応答は実験より縮約 系による推定に近く，この場合は縮約法や等価線形化による誤差は 小さく, 復元力特性の設定など非線形地震応答解析の誤差がむしろ 大きいことがわかる。 

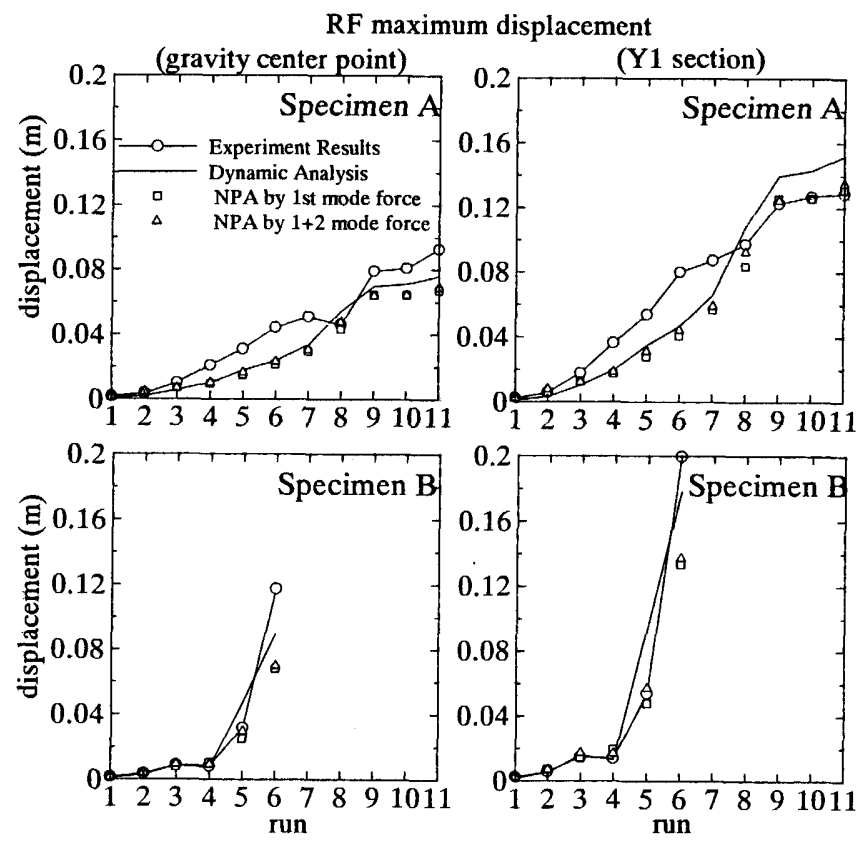

図 4 最上階の最大応答と解析応答值の比較

\section{4. 多層偏心構造物の非線形地震応答の一般性状}

\section{1 動的解析による最大応答とモード形の抽出}

偏心構造物の非線形地震応答解析には実験の入力に用いた兵厚県 南部地震神戸海洋気象台の記録 (KOBE), チリ地震 (CHILE) の 2 波に加之て，標準的な設計用地震動として日本建築センタ一の模擬 波（BCJL2）を用いた。また，構造物の塑性化の程度が異なる場合 を一般的に検討するために，地震の大きさを原波の定数倍（BCJL2 では0.5倍刻み，CHILE，KOBEでは0.25倍刻み）で変化させて解 析結果を整理した。静的漸増解析 (NPA) では異なる2つの外力分 布形，すなわち，(1) 1 次モード形，(2) 1 次と 2 次の重ね合せ ((1)式, 以下， $(1+2)$ 次外力分布，という)，(3)後述与る提案手法，を仮 定して結果を比較している。

動的解析から抽出された変形モード形の 1 次有効質量比 $M_{1}$ と抽

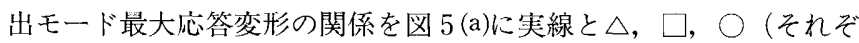
れ，CHILE，KOBE，BCJL2入力)で示した。同様に異なる外力分 布に対する静的解析における变形と変形実線（2） 1 次と 2 次の重ね 合わせ）で示した。

動的応答時の 1 次有効質量比は概补 2 つの外力分布形による NPA 結果の有効質量比の間にあり，1次モード外力から徐々に重 ね合わせの外力による解析值に漸近し，ややこれを上回る值で定常 化している。この傾向はいずれの入力招よびこれ以外の試験体の場 合でもほぼ共通している13)。

これは試験体が塑性化すると動的岕答から抽出された変形モード が弾性 1 次モードから重ねあわせ外力による変形モードに近い形状 に遷移していることを示している。また，1次有効質量比で代表さ れるモード形が遷移する変形のレベルは入力地震波に依存せず試験 体ごとにほぼ同様である。

これは経験的に設定された手法（1 次と 2 次の重ね合わせによる NPAに上る応答推定)に対応するものであるが，次項で詳細に検討 するように 1 次と 2 次モードの変形成分は塑性化により同位相で振

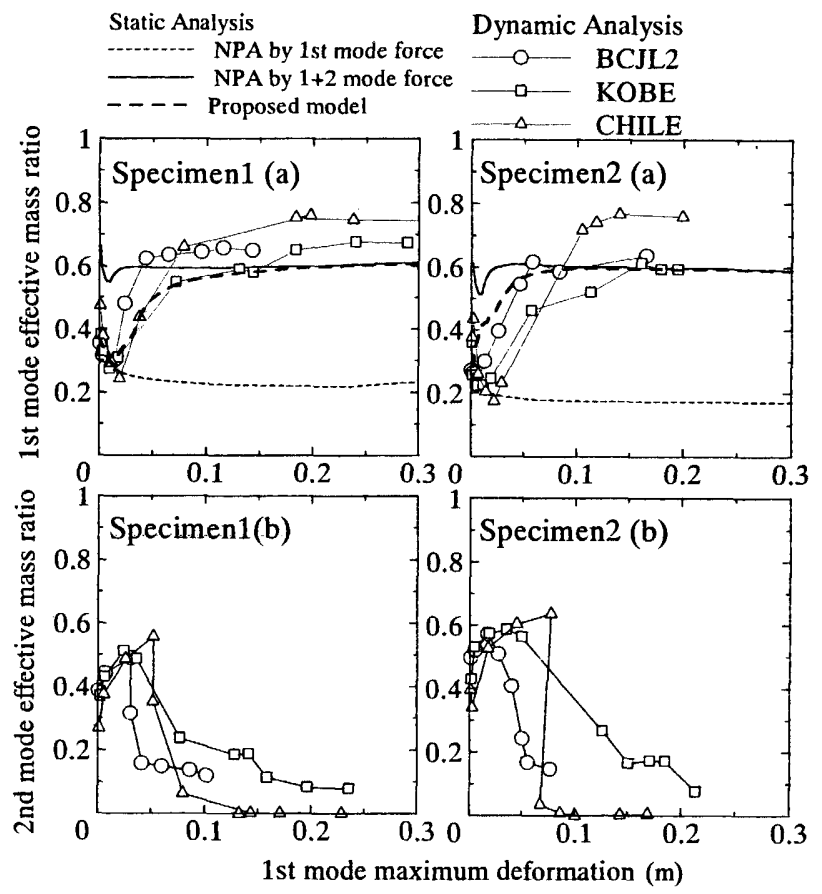

図 5 解析試験体の有効質量比と応答中心の推移

動するようになり，非線形領域で一定のモード形として抽出された ためであると推察される。

図 5 (b)に動的解析時の 1 次基準モードの最大応答変形に対する抽 出された 2 次モ一ド有効質量比 $M_{2}$ の推移を示す。試験体の 2 次有 効質量比は徐々に減少し，0に漸近している。守なわち，単位入力 加速度あたりの 2 次変形に奇与する外力成分が 0 に漸近し。動的応 答は抽出された 1 次基準モ一ドのみで縮約した系の応答で推定可能 になることを示唆している。

\section{2 変形モードと相対加速度の位相相関}

抽出変形モードが $(1+2)$ 次外力分布による変形モードに漸近

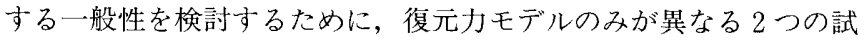
験体の非線形応答を比較した。試験体 1 の復元力特性は全て RC (武 田）モデル $(\alpha=0.5)$, 試験体 2 の復元力特性は非線形弾性モデルと した。すなわち，復元力特性の包絡線(ひび割れ，降伏点荷重およ び剛性低下率）は共通であるが除荷剛性のみが異なる。また，弾性 応答と弾塑性志答を比較するために入力は $\mathrm{KOBE}$ 原波を0.1倍 〜3.5倍した。

図 6 に 2 試験体の抽出モ一ドの相対加速度（外力）波形をそれぞ れ破線（弾性志答，0.1倍）と薄線（弾塑性応答，3.5倍）で， 入力 加速度波形を実線で示した。位相を比較するためいずれも振幅は最 大值で基準化している。試験体 1 の弾性応答, 試験体 2 から抽出さ れるモ一ド形は弾性, 弾塑性応答とも相対加速度波形と入力加速度 波形の相関性は低くそれぞれ独立の応答波形を示す。しかし，大き く塑性化した試験体 1 では入力加速度とほぼ逆位相の相対加速度が 抽出されている。この傾向は RC モデルで塑性化が進行するほど明 瞭になるが，非線形弾性モデルでは生じない。

これは既往の研究8)でも指摘されている傾问であり, 非線形応答 との誤差の累積二乗値を最小として抽出されたモ一ドに特有の性質 であるとも考えられるが，非線形弾性ではみられないことから，塑 
性化そのものではなく，塑性化が進行して除化方向と載荷方向で剛 性が異なる（分岐する）復元力特性の性質に依存して生じる現象で あると推定される。

相対加速度が入力加速度と逆位相になるという性質は非線形応答 波形の中でモード変形が進行する方向の相対加速度（外力）成分の みが抽出されており，モード外力を重ね合わせた静的解析結果で最 大変形を推定しうる根拠を示している。
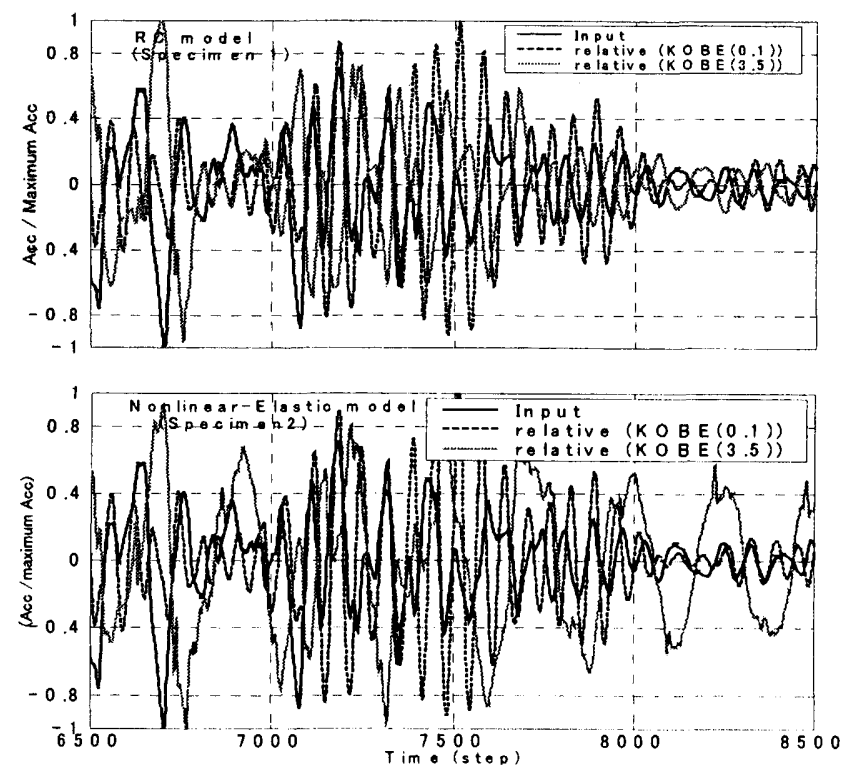

图 62 侙験体の抽性相刘挑速度波形の比較

困 7 に入力の大きさを 0.1 - 3.5倍に漸增させた時の抽恔形モ一 ドの有効質量比の変化を実線（1次）と破線（2次）で示した。 RC モデルでは抽出 1 次変形モードの存効質量比は塑性化に応じて徐々 に大きくなり，2次は徐々に減少するのに対して，非線形弾性モデ ルではこの傾问は光られなかった。これらの解析結果から，抽计変 形モードが $(1+2)$ 次外分分布による変形モ一ドに漸近する理由 は変形に心じて抽出される相対加速度の位相が入加速度の逆位相 に近づくという一般的な傾问に基づくことが明らかになった。

\section{5 . 応答推定手法の提案}

\section{1 モード形の設定}

動的応答において 1 次有効質量比が弾性 1 次モードの外力分布に よる静的解析值と異なり始める変形は代表点の荷重変形関係におけ る降伏変形付近である。これは非線形化によって弾性に近いモード 形およびモードの直交性が崩れるためであると考えられる。

NPA では通常外力分布は固定されるが，動的解析では外力分布 は非線形化後も変化する。したがって，変形モードと外力モードが 質量を介して対応する（固有モ一ド）変形を静的解析から求めるの は困難である。そこで動的応答から抽出された 1 次変形モードが $(1+2)$ 次外力分布による変形モードに定常化する変形は弾性モ一 ド形を重ね合わせた一定の外力分布による静的解析の結果，変形 モード形の応答中心点の変化が定常化する変形として算定する。

動的応答時の有効質量比の遷移から抽出された 1 次基準モ一ドの

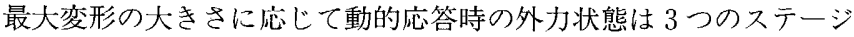

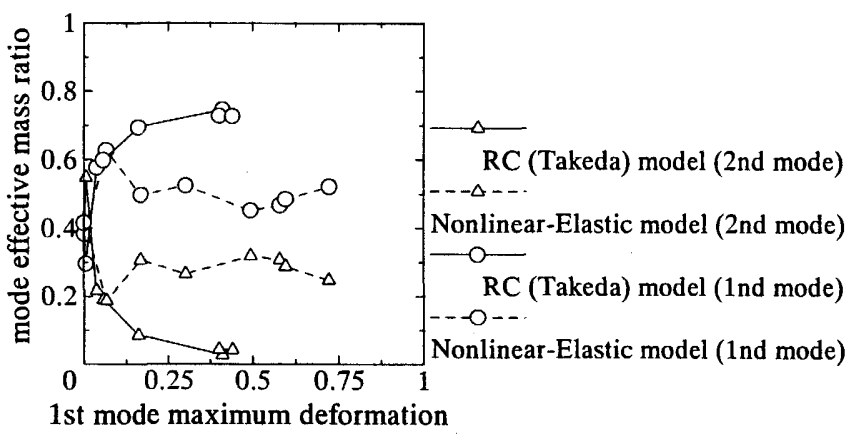

図 72 試験体の有効質量比の推移

に区分することができる。第 1 段階は抽出 1 次変形が原点から降伏 点変形までの変形となる場合である。動的な 1 次外力分布は弾性 1 次モード外力分布と同值となり，忘答変形は 1 次と 2 次モードの変 形を重ね合わせたものになり，MPAによる推定が可能であると子 想される。第 2 段階は抽出 1 次変形が降伏点から変形モードの応答 中心が定常化する変形までの変形となる場合である。動的 1 次外力 分布は 1 次モ一ド外力分有から $(1+2)$ 次モ一ド外力分布に漸近 する。応答変形はその動的 1 次外力から静的解析によって求まる 1 次変形に降伏後徐々に小さくなる 2 次モ一ド外少分有による2次変 形を㞦之た㑬となる。第 3 段階は抽忺 1 次変形が変形モードの答 中心点が定崩化する変形以上の変形となる場命である。動的 1 次外 力分布は $(1+2)$ 次モード外为分们となり変形は 1 つの起モード のみによる NPAで維約して推走することができるとチ想される。

そこで，本解析では動的解析時に抽忡された徙モード形に基づい た外分分布を用いて非線形忘答を推起する乎法を提策し，既往の推

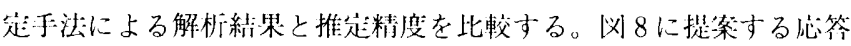
推定于法のフロー刚を示す。

有効質鱼比は第 2 段階においてモード変形に刘して比例的に濑近 している。また振動方程式からこの储は縮約系にかかる外力の分布 に対忍することから静的解析に扮ける動的外力状態は線形補閏する ことで近似する。

まず1次モード外分布と $(1+2)$ 次モード外力分布をそれぞ れ降伏点外力と変形モードの忘答中心が定常化する変形に扩ける外 力間で線形補間した外力分布でNPA を行い，1 次変形を求める。次 に 1 次変形の大小に応じて, 第 1 段階では MPAによって, 第 3 段階 ではNPAによって非線形応答を推定する。第 2 段階において 2 次 モード変形は弾性範囲に留まるものとする。応答推定值は 1 次モ一 ド外力による 1 次変形に 1 次変形に応じて線形的に小さくなる 2 次 モード外力による 2 次変形を加えた值とする。

\section{2 有効質量比の推移の比較}

図 5 (a)に破線で提案した外力分布で静的解析を行った場合の有効 質量比の推移を示す。提案する外力分布形で静的解析することに よって有効質量比の推移は動的応答から抽出される変形モードの有 効質量比に概ね対応することがわかる。

\section{3 最上階応答中心の推移の比較}

偏心構造物は並進変形と層回転変形の足し合わせにより最大変形 が決定する。したがって，等価線形応答の変形モードは非線形応答 


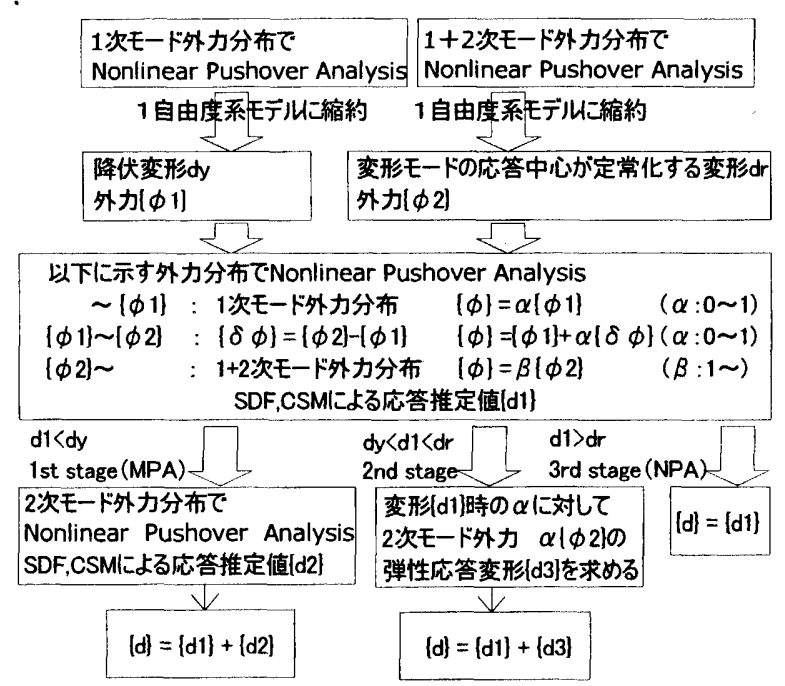

图 8 提案する応答推定手法のフロー図

の 1 次基準変形モードにおける 2 つの変形成分の割合を再現する必 要がある。

図 9 に動的解析および異なる 3 つの外力分布形による静的解析 (1) 1次；(2)1，2次の重ね合わせ；(3)提案した外力）を行った場合 の変形モ一ドについて最上階の並進変形成分に対する回転変形成分 の比（重心と応答中心間の距離の逆数）の推移をそれぞれ点線，実 線, 破線で示寸。抽出した 1 次変形モ一ドの応答中心は変形に応し て1次モード外力分布に上る静的解析值から $(1+2)$ 次モ一ド外 力分有による解析值に近づく。捉案した外力で静的載荷した結果, 変形モードは応答中心が動的応答から抽出された 1 次変形モードの 值に近似し，応答中心という点でも1次変形モードを再現しうる。

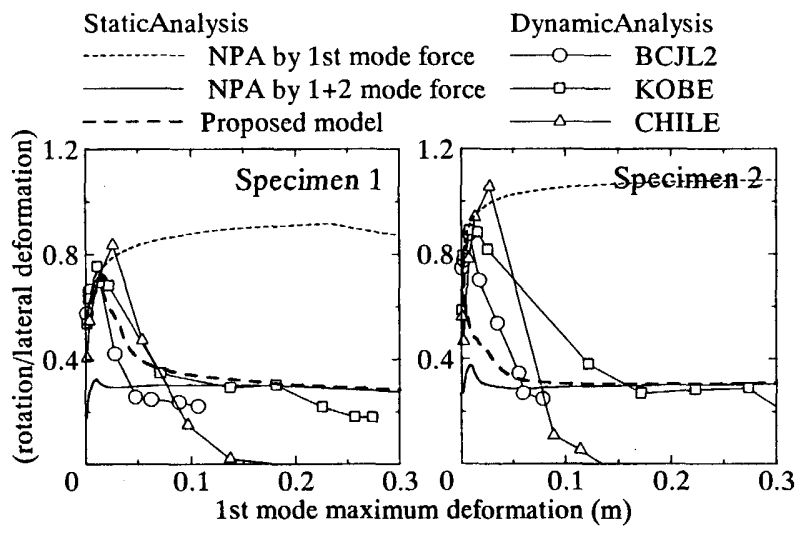

図 9 最上階の並進変形に対寸る層回転変形の比の推移

\section{4 最大応答变形の比較}

図10に既往の NPA を用いた場合（破線）と提案した推定手法（実 線）を用いた場合の等価線形応答の最上階重心および X1構面の加 震方向の最大応答值（\#1）を比較した。グラフの横軸には非線形応 答解析の最大応答值（\#2）とし縦軸には非線形応答值に対する等価 線形応答值誤差の比 $((\# 2-\# 1) /(\# 2))$ とした。提案する手法は 2 次 変形を加えた値・引いた值のうち非線形応答に近似している值でプ ロットした。

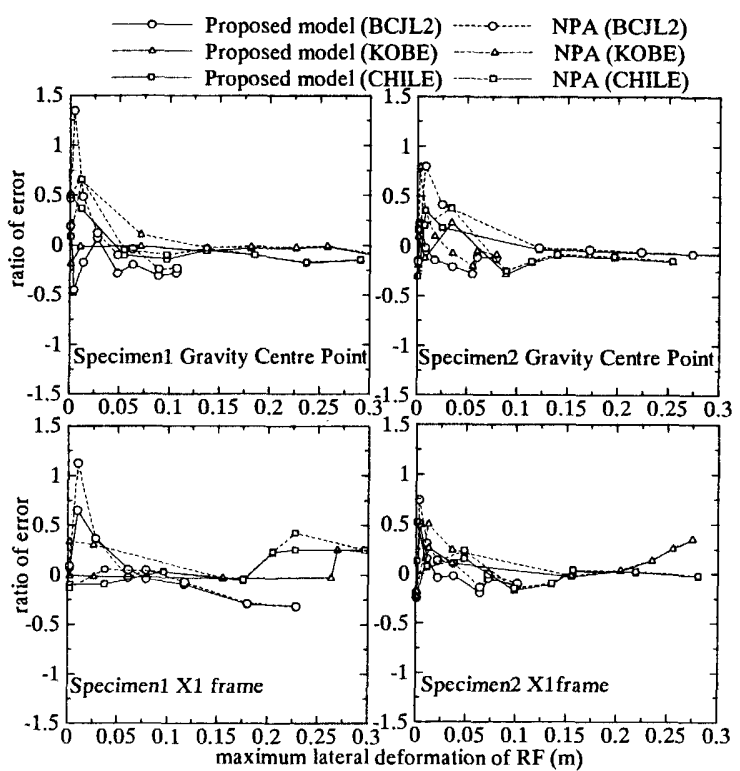

図10最上階重心扝よび X1構面の最大忍答推定の推移

両試験体について重心・X 1 構面ともに最大水平変形角が $1 / 33 \mathrm{rad}$ 以上になる場合は既往の等価線形化手法 (NPA) でも十分な精度で 推定可能であった。すなうち弾性モードの 1 次有効質量比が小さく ても応答変形が非常に大きな範囲では既往の等価線形化手法も有効 であった。一方, 最大水平変形角が $1 / 33 \mathrm{rad}$ 以下の範囲の非線形応答 值は概ね提案する手法による MPA 推定值の間にあり，提案する手 法により推定精度が若干向上した。各次応答モードの同時性を考虑 した手法を用いることで推定値の誤差はさらに小さくなると推察さ れる。

\section{6. 既往の研究結果との比較}

\subsection{2 軸偏心構造物}

外力方向の変形に対する一軸偏心の構造物であっても，㨝れモ一 メントによって生じるせん断力によって加震直交力向構面が剛性低 下して層回転角が加震直交方向の耐力に依存する耐力偏心となり， 辇質的な二軸偏心になりうる。

藤井はこれにより一次有効質量比が低下する可能性があることを 指摘しており，さらに等価線形応答で推定可能な構造物の判定方法 として1 次モード外力で静的解析し, 変形モードの有効質量比の下 限值をとることを提案している7)。

しかし，本研究では非常に弾性 1 次モ一ド有効質量比の小さい構 造物においても抽出される変形モードが 1 つの変形モ一ド形(( $1+$ 2）次モード）に溸近し，等価線形态答の推定精度は高くなりうる ことを示した。

NPA 手法では 3 次元立体構造物としてモデル化しているので, 直交方向の㴊性や偏心，非線形化の影響は必然的に考慮される。 2 軸偏心構造物である震動試験体の静的解析では抽出変形モードの有 効質量比は徐々に低下して抢り，㨝れモーメントによる直交方向構 面の剛性低下，層回転変形の増大を示している。したがって 2 軸偏 心などによって直交方向構面が㴊性低下寸る場合の変形モードも $(1+2)$ 次モード外力分布によるNPA から推定叮能であることが 
確認された。

\section{2 耐力偏心率との対応}

偏心構造物の各構面が全て降伏した場合, 起こりうる最大偏心 モーメントは各部材の降伏耐力から求められる。この值に基づき非 線形領域における偏心忍答性状を表寸指標に耐力偏心率があり, 加 震直交方向構面の塑性化を考慮しなければ非常に大きな変形領域に おいて重心位置の最大層回転角に比例することが指摘されてい $3^{14)}$ 。

この指標は構造物の部材が全て降伏していることを前提としてい るため, 部材の岡性が低下せず，各部材の岡性マトリクスを累加し た全体剛性マトリクスが変化しない変形領域に打ける偏心応答性状 と対応する。本解析において動的応答の第 3 段階は変形モードと外 力モードが質量を介して対心する(固有モード)，すなわち外力分布 がー定であれば変形が䇥モードを亦す変形領域と定義した。この変 形領域は全体阙性マトリクスの変化がない変形領域とほぼ一致し， 耐力偏心率を定義する変形では変形モードが㳬まる。

したがって, 酎力值心率により保心構造物が全体降伏機構を形成 する伈答変形を簡略的に評洒することができる。すなわち，本研究

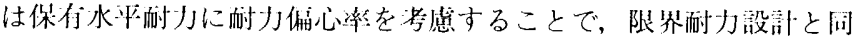

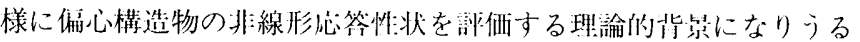
絬果をふしたことになる。

\section{7. 結論}

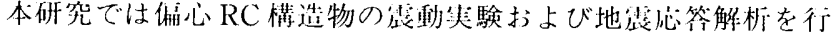
い, 等俇線形化による忍答推起法に咸して以トの点を明らかにした。

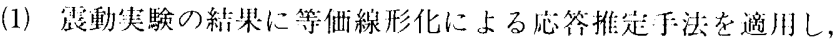
NPA F法が受当であることを確琹した。(2) 1 次存效钼高比が大 きい構选物は 1 次モード変形が古越するので 1 次モードのみ考虑し

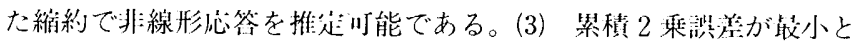

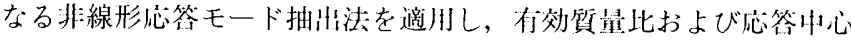
点の推移により，捉れ忘答モードの性状を分析する乎法を正しした。

(4) 1 次付效質星比が小さい場合でも，抽出される変形モードの有 效質晕比は塑性化が進むと弾性 1 次モードの值から 1 次と 2 次モ一 ドの車ねあわせ外力分布による NPA 解析值に漸近する傾向がある ことをホした。(5) この傾向は塑性化すると非線形态答から抽出さ れる相対加速度の位相が入力加速度の逆位相に近づくという一般的 な性質により生じることを明らかにした。またここの性質は RC 復元 カモデルの除荷㴊性への分岐に起因している可能性を示した。(6)
この傾向を利用して NPA, MPA を組み合わせた動的応答に基づく モード形で非線形応答を推定する手法を提案した。(7) 塑性化の程 度が非常に大きい場合は 1 次有効質量比が小さい場合でも既往の NPA 手法によっても非線形応答を高精度で推定可能である。(8) 提案した手法により有効質量比あるいは変形レベルによらず一般的 な推定が可能になった。(9) 2 軸偏心の問題に関しても，震動実験 で生じた有効質量比の推移は, 3 次元の NPA 解析によって把握し うることを確認した。(10) 保有水平耐力に耐力偏心率を考虑して偏 心構造物の非線形応答性状を簡易に評価する設計法が可能になる理 論的背景を示した。

\section{参考文献}

1) Anil K. Chopra, Rakesh K. Goel: Modal Pushover Analysis symmetric and unsymmetric plans buildings, International Workshop on PBSD Concepts \& Implementation, 2004.7

2) Anil K.Chopra, Rakesh K. Goel: A Modal Pushover Analysis Precedure to Estimate Seismic Demands for Buildings, $A$ report on research conducted under grant no. CMS-9812531 from the National Science PEER Report, 2001.3

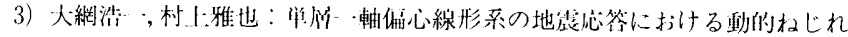

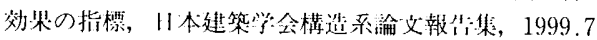

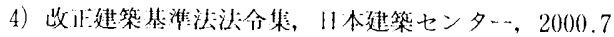

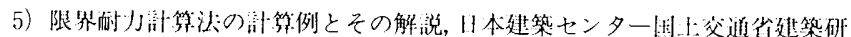

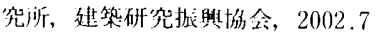

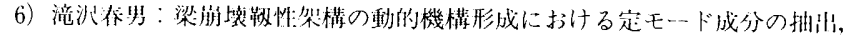

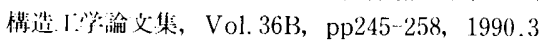

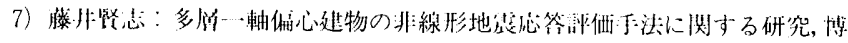
1.湴文, 2003.2

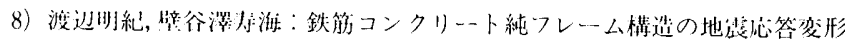

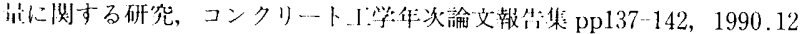

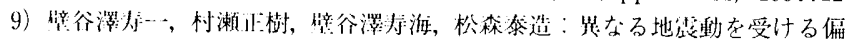

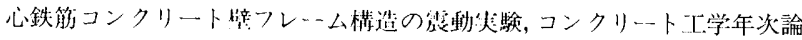
文報售第26卷，No. 2，pp1159-1164，2004.7

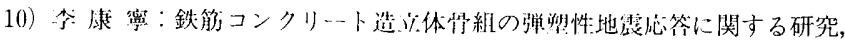
博 E諭文， 1988.12

11）壁谷澤寿海，篮原 等, 小谷俊介, 青山博之：鉄筋コンクリート造実大 7 啗試験体の耐祳性に関する研究（その3）疑似動的解析第 6 回日本地震工 学シンポジウム講演集, pp1161-1168, 1982.12

12）鉄筋コンクリート造建物の靱性保証型耐震設計指針・同解説，日本建築学 会編， 1999.7

13）壁谷澤寿一：偏心鉄筋コンクリート構造物の等価線形化に関する研究, 修 土論文， 2005.3

14）藤井賢志：せん断破壊を伴う単層鉄筋コンクリート造建物のねじれ地震 忘答性状, 修士論文, 2000.2

(2005年 3 月 8 日原稿受理，2005年 6 月 29 日採用決定) 